\title{
Experimental validation of multiphase flow models and testing of multiphase flow meters: a critical review of flow loops worldwide
}

\author{
O. O. Bello ${ }^{1}$, G. Falcone ${ }^{2}$ \& C. Teodoriu ${ }^{2}$ \\ ${ }^{I}$ Clausthal University of Technology, Institute of Petroleum Engineering, \\ Germany \\ ${ }^{2}$ Texas A\&M University, Department of Petroleum Engineering, USA
}

\begin{abstract}
Around the world, research into multiphase flow is performed by scientists with hugely diverse backgrounds: physicists, mathematicians and engineers from mechanical, nuclear, chemical, civil, petroleum, environmental and aerospace disciplines. Multiphase flow models are required to investigate the co-current or counter-current flow of different fluid phases under a wide range of pressure and temperature conditions and in several different configurations. To compliment this theoretical effort, measurements at controlled experimental conditions are required to verify multiphase flow models and assess their range of applicability, which has given rise to a large number of multiphase flow loops around the world. These flow loops are also used intensively to test and validate multiphase flow meters, which are devices for the in-line measurement of multiphase flow streams without separation of the phases. However, there are numerous multiphase flow varieties due to differences in pressure and temperature, fluids, flow regimes, pipe geometry, inclination and diameter, so a flow loop cannot represent all possible situations. Even when experiments in a given flow loop are believed to be sufficiently exhaustive for a specific study area, the real conditions encountered in the field tend to be very different from those recreated in the research facility. This paper presents a critical review of multiphase flow loops around the world, highlighting the pros and cons of each facility with regard to reproducing and monitoring different multiphase flow situations. The authors suggest a way forward for new developments in this area.
\end{abstract}

Keywords: multiphase flow loop, multiphase flow modelling. 


\section{Introduction}

Multiphase flow can occur in pipes as well as in porous media. The focus of this paper is on the former, although it will be shown that more research on the interaction between multiphase flows in porous media and those in pipes is needed, both theoretical and experimental.

Multiphase flows consist of the simultaneous passage through a system of a stream composed of two or more phases. They are very common natural phenomena: the flow of blood in our body, the rising gas bubbles in a glass of beer and the steam condensation on windows are all examples of naturally occurring multiphase flows.

However, it the large scale multiphase flows, such as those that occur in the petroleum industry, on which this paper will focus. For example, in a typical oil and gas development, multiphase flow is encountered in the wells, in the flow lines and risers transporting the fluids from the wells to the platform and in the multiphase flow lines that carry the produced fluids to the treatment facilities at shore.

Multiphase flow systems can be very complex, due to the simultaneous presence of different phases and, usually of different compounds in the same stream. Thus, the development of adequate models presents a formidable challenge. The combination of empirical observations and numerical modelling has proved to enhance the understanding of multiphase flow.

Models to represent flows in pipes were traditionally based on empirical correlations for hold-up and pressure gradient, but it is more usual nowadays to use codes based on the multi-fluid model, in which averaged and separate continuity and momentum equations are written for the individual phases. For these models, closure relationships are required for interface and pipe wall friction.

To compliment the theoretical effort, experimental measurements under controlled conditions are required to verify multiphase flow models and assess their range of applicability. This is why there exists a large number of multiphase flow loops around the world, each of them with specific capabilities and limitations.

This paper attempts to review all the major world-wide facilities that allow a wide range of two- and three-phase flow experiments, but the authors accept that their review may not be exhaustive. Flow loops may be operated by academic organisations, independent research centres or individual companies and there is a special category for oil and gas applications, where real hydrocarbon fluids and field operating conditions are used.

The review is based on information available in the public domain and focuses on large scale facilities. This choice reflects the specific need for multiphase flow loops for studies related to hydrology, petroleum and environmental engineering, geothermal energy plants, underground gas storage and $\mathrm{CO}_{2}$ sequestration. For studies on nano-technology, life science and medical systems, different flow loops are necessary to reproduce "reality" in a laboratory. 
Finally, there are ad hoc facilities for the investigation of boiling and condensation processes and for nuclear engineering applications.

No flow loop can be representative of all possible situations. Even when experiments in a given flow loop are believed to be sufficiently exhaustive for a specific study area, the conditions that will be encountered in a real application can be very different from those recreated in the research facility.

The objective of this paper is therefore to review some of the major worldwide flow loop facilities for two- and three-phase flow investigation that are reported in the public domain, to point out unresolved problems in reproducing real processes in a laboratory environment.

\section{Multiphase flow}

The phases present in a multiphase flow are: solid, which is incompressible and has non-deformable interfaces with the surrounding fluids; liquid, which is relatively incompressible, but has deformable interfaces with the other phases; and gas, which is compressible and deformable. The different phases of a multiphase flow may consist of different chemical substances. It is also possible to have the two phases of a two-phase flow made of the same pure component.

Two-phase flows include:

(1) Gas-solid flows, where solid particles are suspended in gases.

(2) Liquid-liquid flows, as in oil-water emulsions in pipelines.

(3) Liquid-solid flows, where solids are suspended in liquids.

(4) Gas-liquid flows, which is the flow most widely found in industrial applications.

Three-phase flows include:

(1) Gas-liquid-solid flows, as in froth flotation for the separation of minerals.

(2) Gas-liquid-liquid flows, as in natural gas-oil-water.

(3) Solid-liquid-liquid flows, as in sand-oil-water.

Four-phase flows are the most difficult case and include:

(1) Liquid-liquid-gas-solid, as in oil-water-gas-sand (or asphaltenes or hydrates) mixtures.

Flow regimes. The shape and behaviour of the interfaces between phases in a multiphase mixture dictate what is referred to as "flow regime" or "flow pattern". There are competing forces or mechanisms occurring within the multiphase fluid at the same time. The balance between them determines the flow pattern.

Flow pattern classifications were originally based on visual observations of two-phase flow experiments, which were mapped on two-dimensional plots (called "flow pattern maps") and the boundaries between regimes determined. Different investigators used different coordinates for the maps (e.g. mass flow rates, momentum fluxes or superficial velocities), in search for parameters that were independent of the given experimental set-up. Inevitably, the judgement of the observed regime was very subjective.

For three-phase flow, the investigation of oil-water-natural gas flow regimes for the petroleum industry immediately showed the complexity of defining the 
liquid-liquid mixing patterns, superimposed on the existing complexities of flow regimes arising from the gas-liquid interactions per se' [1].

The factors that dictate the flow pattern of a multiphase flow are: the fluid properties; the operating pressure and temperature; the pipe diameter, shape, inclination and roughness; and the presence of any upstream or downstream pipe work (e.g. choke valves, T-junctions).

Even more complexity is introduced when trying to define the flow regime under transient flow conditions; when all the key flow parameters are changing in time and space.

More recently, visual observations have been combined with a modelling effort.

\section{Multiphase flow modelling}

Briefly, multiphase flow models can be categorised as follows [2].

- Empirical: data for frictional pressure gradient and void fraction are related to system variables through empirical equations. A thorough review of the historical development of empirical multiphase flow models for hydrocarbon mixtures is given in [3]. The empirical models are the simplest and fastest to run, but their accuracy may be unacceptable outside the range of applicability for which the models were developed and validated. On the other hand, the more rigorous and complex models, based on the numerical solution of the conservation equations, are costly, time consuming and have intrinsic problems with convergence and the definition of the closure relationships. Such problems become even more important when solutions for transient flow are sought.

- Multifluid: formal governing equations (mass, momentum and energy) are solved with appropriate closure laws (usually based on empirical data). An evaluation of mechanistic two-phase flow models is given in [4]. The multifluid models do not cope well with intermittent flows. In slug flows, for instance, the liquid phase flows upwards in the slugs, but downwards in the Taylor bubble regions. This type of intermittency makes averaging difficult and does not fit well in a multi-fluid model framework.

- Phenomenological: observations are made of the flow patterns and models constructed with appropriate closure laws to represent the flow based on the pattern features. An example of flow models of this type is discussed in [2]. The flow regime boundaries are established through transition models (e.g. the model of Hewitt and Jayanti [5] for the slug-churn transition) and each regime is modelled by taking account of the phenomena occurring within it (such as droplet entrainment and deposition in annular flow).

- Interface tracking: calculates the details of the interfacial structure by various techniques. A review of interface tracking methods is given by [6]. The applicability of interface tracking methods is usually limited to simple flow configurations. 


\section{Review of existing flow loops}

In the following text, a selection of major flow loops is presented and reviewed. A thorough investigation and ranking of world-wide flow loops for multiphase flow experiments should include all of the following factors: loop geometry, dimensions, operating pressure and temperature, range of phase flow rate, equipment and instrumentation, piping material, fluid properties, data acquisition and information processing systems. However, the objective of this paper is to illustrate how to approach such an investigation and to identify future needs for niche experimental investigations. Thus, only a selection of the above key parameters that define the potential of a flow loop was considered for this study.

\subsection{Distribution of flow loops world-wide}

The locations of the flow loops identified for this study are indicated in Table 1. The authors were unable to find details of flow loops in certain regions of the world (e.g. former Soviet Union, Eastern Europe and Asia), although it is quite possible that facilities do exist there. A general observation is that the facilities are located either in areas of large scale oil and gas production (e.g. Norway, UK and USA) or in areas where research on nuclear power is important (e.g. UK, France, USA and Germany).

\subsection{Common aspects of flow loop design}

No flow loop can represent of all possible multiphase flow situations, instead a loop is built to meet a specific need or to mimic a specific process. However, some recurrent design aspects of multiphase flow loop facilities are evident, such as low-pressure flow loops tend to have pipes made of polyvinyl chloride (PVC) material, with special test sections made of Perspex or transparent PVC material. This feature allows visual investigation of the flow to identify flow patterns. High-pressure facilities, on the other hand, are built with carbon steel or stainless steel pipe work. To protect the carbon steel against corrosion, inhibitors are added to the test fluids. One loop only is reported to be made of Copper [7].

There is also a trend in the type of fluids used for multiphase flow experiments. Water and air prevail, although stabilised oil, kerosene and nitrogen are becoming more commonplace for studies related to oil and gas applications. For investigations focused on flow pattern identification, inert tracers are often used to enhance the contrast between phases.

Finally, all flow loops adopt similar strategies regarding the choice of equipment (e.g. valve, compressors and pumps) and instrumentation (e.g. pressure transducers and hold-up measurement systems).

\subsection{Flow loop capabilities}

Each flow loop, in the database created by the authors, has been classified according to the following criteria: total reported length, maximum working diameter, inclination, operating pressure, length of test section and type of fluid. Table 1 summarises the flow loops selected for this review. 
Table 1: $\quad$ Selection of flow loops reviewed in this paper.

\begin{tabular}{|c|c|c|c|c|}
\hline Notation in this paper & $\begin{array}{c}\text { Flow } \\
\text { direction }\end{array}$ & Fluids/Piping & $\begin{array}{l}\text { Diameter } \\
\text { [mm] }\end{array}$ & Ref. \\
\hline $\begin{array}{l}\text { SINTEF* } \\
\text { (SINTEF Petroleum Research), } \\
\text { NO }\end{array}$ & $\begin{array}{l}\text { Horizontal \& } \\
\text { vertical }\end{array}$ & $\begin{array}{l}\text { Hydrocarbons, } \\
\mathrm{H}_{2} \mathrm{O}, \mathrm{N}_{2} \\
\text { Carbon steel / PVC }\end{array}$ & $\begin{array}{l}100 \\
200 \\
304.8\end{array}$ & {$[4,8]$} \\
\hline $\begin{array}{l}\text { SwRI } \\
\text { (South West Research Institute), } \\
\text { US }\end{array}$ & Vertical & $\begin{array}{l}\text { Gas, water } \\
\text { Carbon steel }\end{array}$ & 25.4 & [9] \\
\hline IFE, NO & Vertical & N/A & 100 & [31] \\
\hline $\begin{array}{l}\text { NFL } \\
\text { (Memorial University of } \\
\text { Newfoundland), CA }\end{array}$ & Vertical & & 76.2 & [30] \\
\hline TUFFP1 (Tulsa), US & Vertical & N/A & & [32] \\
\hline TUFFP2 (Tulsa), US & $\begin{array}{l}\text { Hilly terrain, } \\
\text { horizontal }\end{array}$ & $\begin{array}{l}\text { N/A } \\
\text { Carbon Steel }\end{array}$ & & [32] \\
\hline $\begin{array}{l}\text { NEL (National } \\
\text { Eaboratory), UK }\end{array}$ & Vertical & $\begin{array}{l}\text { N/A } \\
\text { Carbon Steel }\end{array}$ & & {$[23]$} \\
\hline $\begin{array}{lll}\text { IFP (Institut } & \text { Français } & \text { du } \\
\text { petrole), FR } & & \end{array}$ & Vertical & $\begin{array}{l}\text { Air, water } \\
\text { Carbon steel }\end{array}$ & 4 & [23] \\
\hline $\begin{array}{l}\text { CRAN (Cranfield University), } \\
\text { UK }\end{array}$ & Horizontal & $\begin{array}{l}\text { N/A } \\
\text { Carbon steel }\end{array}$ & 250 & [14] \\
\hline $\begin{array}{l}\text { BHRA (BHR Group Limited), } \\
\text { UK }\end{array}$ & Horizontal & $\begin{array}{l}\text { Stainless } \quad \text { Steel/ } \\
\text { PVC }\end{array}$ & $\begin{array}{l}200 \\
400\end{array}$ & [28] \\
\hline SHELL (Rijswijk), NL & $\begin{array}{l}\text { Horizontal \& } \\
\text { vertical }\end{array}$ & $\begin{array}{ll}\text { Stainless } & \text { Steel/ } \\
\text { Perspex pipe } & \end{array}$ & 82 & [29] \\
\hline $\begin{array}{l}\text { ITE } \\
\text { (Petroleum Engineering Institute } \\
\text { of TU Clausthal), DE }\end{array}$ & $\begin{array}{l}\text { Horizontal \& } \\
\text { vertical }\end{array}$ & $\begin{array}{l}\text { Air/water/sand } \\
\text { Plexiglas }\end{array}$ & 40 & {$[21]$} \\
\hline $\begin{array}{lll}\text { TAMU1 (Texas } & \text { A\&M } \\
\text { University), US } & \end{array}$ & Vertical & $\begin{array}{l}\text { Air/water } \\
\text { Transparent PVC }\end{array}$ & 127 & {$[10]$} \\
\hline $\begin{array}{l}\text { CSM (Colorado school of } \\
\text { Mines), US }\end{array}$ & Vertical & $\begin{array}{l}\text { N/A } \\
\text { Transparent PVC }\end{array}$ & $\begin{array}{ll}52, & 140, \\
153.2 & \end{array}$ & [27] \\
\hline $\begin{array}{l}\text { MPC (Middle East Technical } \\
\text { University), TR }\end{array}$ & Horizontal & $\begin{array}{l}\text { Water and air } \\
\text { Transparent PVC }\end{array}$ & $57,114.3$ & {$[26]$} \\
\hline $\begin{array}{l}\text { CEESI } 1 \text { (Colorado Engineering } \\
\text { Experiment Station, Inc.), US }\end{array}$ & $\begin{array}{l}\text { Special flow } \\
\text { (Hydrates) }\end{array}$ & $\begin{array}{l}\text { Water, gas, } \\
\text { hydrates } \\
\text { N/A }\end{array}$ & & [24] \\
\hline $\begin{array}{l}\text { CEESI } 2 \text { (Colorado Engineering } \\
\text { Experiment Station, Inc.), US }\end{array}$ & $\begin{array}{l}\text { High } \\
\text { pressure gas } \\
\text { flow loop }\end{array}$ & $\begin{array}{l}\text { Gas, Oil and water } \\
\text { Carbon steel }\end{array}$ & & {$[16]$} \\
\hline $\begin{array}{l}\text { ICL (Imperial College London), } \\
\text { UK }\end{array}$ & Vertical & $\begin{array}{l}\text { Air/Water } \\
\text { Copper }\end{array}$ & 31.8 & [7] \\
\hline $\begin{array}{lll}\text { WASP } & \text { (Imperial } & \text { College } \\
\text { London), UK } & \end{array}$ & Horizontal & $\begin{array}{l}\text { Water, Air, Sand } \\
\text { and Petroleum } \\
\text { Stainless Steel }\end{array}$ & 76.2 & [25] \\
\hline Atalaia (Petrobras), BR & $\begin{array}{l}\text { Field } \\
\text { equipment }\end{array}$ & N/A & N/A & [18] \\
\hline Trecate (ENI), I & $\begin{array}{l}\text { Field } \\
\text { equipment }\end{array}$ & N/A & N/A & [17] \\
\hline K-Lab (Statoil), NO & $\begin{array}{l}\text { Field } \\
\text { equipment }\end{array}$ & N/A & N/A & [15] \\
\hline
\end{tabular}


Total length. The maximum length of a flow loop affects the development of different flow regimes, particularly when transient flow is investigated. When performing experiments at high gas fractions, the longer the test section, the greater the effect of wellbore storage. Typically, wells used in hydrology, petroleum and environmental engineering, geothermal energy plants, underground gas storage and $\mathrm{CO}_{2}$ sequestration are orders of magnitude longer than the tubes used in experiments. However, as experiments on actual wells are difficult to perform, it is usually assumed that the conditions for flow pattern transitions are similar to those occurring in short tubes. Changes in pipe inclination and flow direction also affect the nature of the flow generated within the system. Some loops have a total length of hundreds of metres, but actual tests sections of just a few metres. The maximum total length found during this review is that of the SINTEF large scale facility $[4,8]$, with approximately 1000 metres of pipe work.

Operating pressure. A flow loop's operating pressure is another key parameter in mimicking real multiphase flow phenomena, especially when compressible fluids are involved. The magnitude of absolute operating pressure, pressure drop in the pipe and pipe length all have an impact on the type of flow regime that can be developed. High pressure facilities are used to extend the validity of empirical multiphase flow models, which were originally developed for lower pressures. During this review, a flow loop was found with a maximum working pressure of $25 \mathrm{MPa}$ [9], while the average pressure for the remaining facilities was found to be equal to or less than $10 \mathrm{MPa}$. If the test sections are made of Perspex or PVC material, the maximum operating pressure is limited to approximately $1 \mathrm{MPa}$. About half of the investigated loops have this operational limitation. The total length versus operating pressure for the selected flow loops is shown in Figure 1.

Length of test section. For multiphase flow investigations related to wells, a vertical test section is needed. Only two flow loops among those considered for this review have a vertical elevation higher than 40 metres: the SINTEF large scale facility [8] and the Texas A\&M PETE Tower Lab (referred to as TAMU1 in the figures) [10]. Besides the difference in pipe diameter, the major difference between these two loops is their maximum working pressures, which are $9 \mathrm{MPa}$ and $0.8 \mathrm{MPa}$, respectively. The vertical height versus operating pressure, for those loops that reportedly have vertical test sections, is shown in Figure 2.

Range of phase flow rates. The range of flow regimes that can be reproduced in a flow loop is related to the flow rates that can be circulated in the system. The maximum reported flow rates of gas, liquid and solids for the flow loops identified for this study are given in Figure 3.

It must be noticed that no indication of the individual phase velocities in a two- or three-phase flow situation is provided in Figure 3. A reference was found [11] where the maximum flow rates of seven flow loops are expressed in terms of phase superficial velocity, as showed in Table 2. However, there is no indication of how the phase superficial velocities vary in relation to different phase fractions. Without this information, it is impossible to assess the full potential of a multiphase flow loop or infer which flow patterns it can reproduce. 


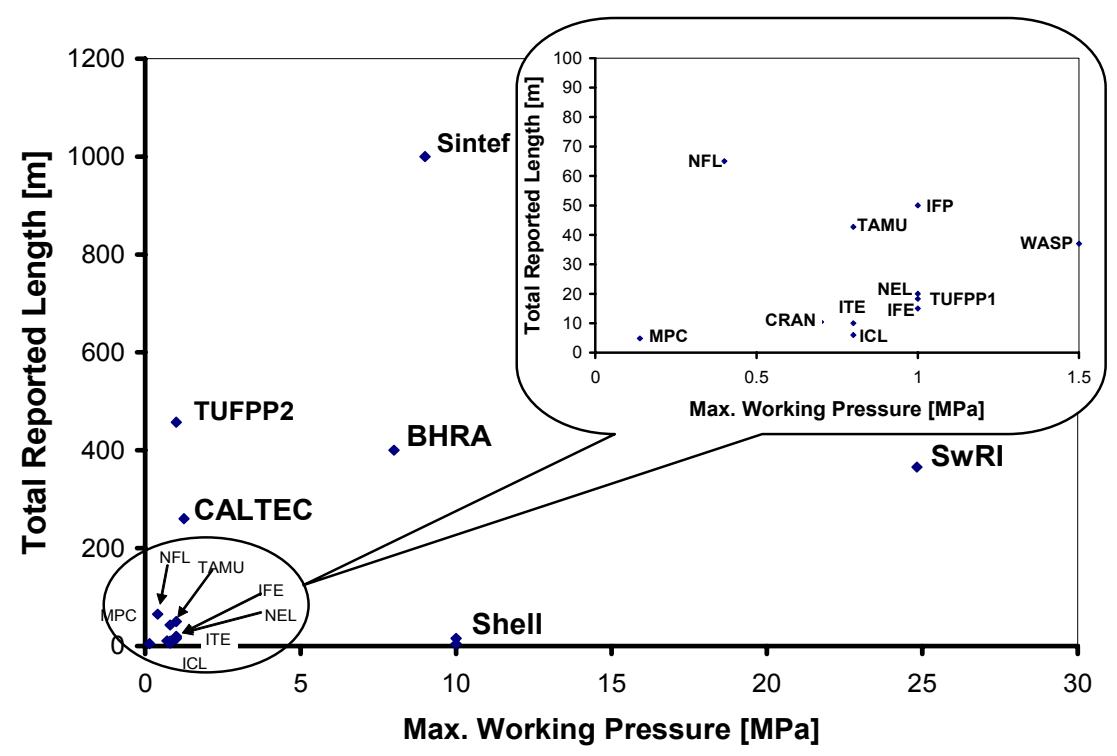

Figure 1: Total length vs. max. working pressure for selected flow loops.

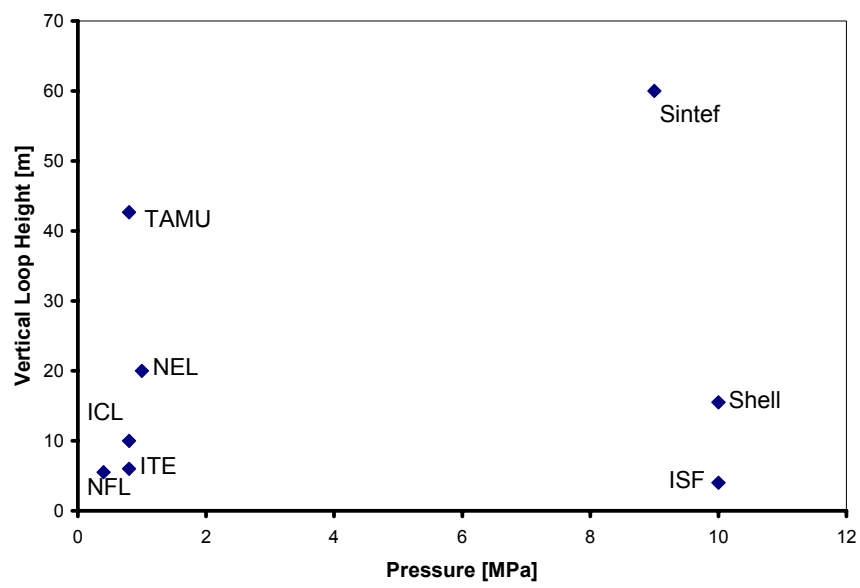

Figure 2: Vertical height vs. max. working pressure for selected flow loops.

Instrumentation. Key flow parameters are required to accurately model multiphase flows and measurements taken during multiphase flow experiments are used to validate and fine-tune the models. Flow loops are therefore equipped with ad hoc sensors and devices to record phase hold-up, temperature, absolute pressure and differential pressure. Each device or sensor can be characterised by its rangeability, repeatability and accuracy of the measurement. Most devices are unable to provide meaningful outputs under transient flow conditions, due to the high instability of key flow features. All of the loops investigated for this study 
have solutions implemented to measure the reference phase flow rates circulated through the system. Table 3 summarises the most common techniques for measuring the reference phase flow rates, the phase hold-up and for identifying the flow patterns.

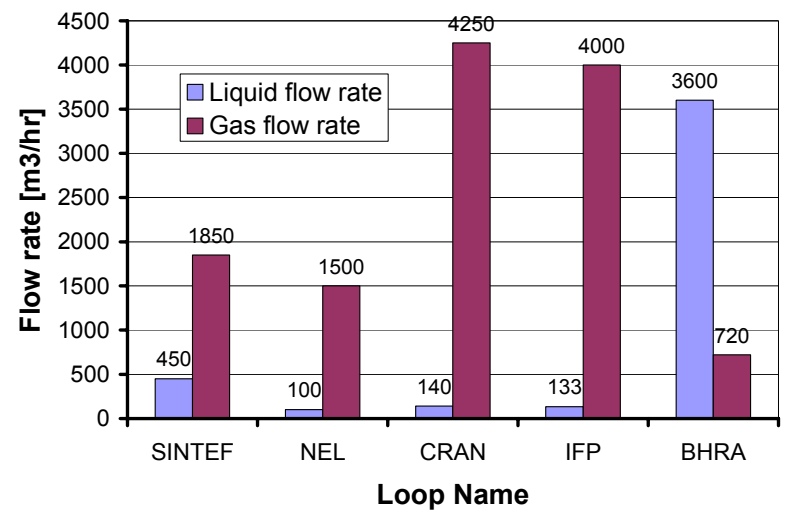

Figure 3: $\quad$ Maximum phase flow rates for selected multiphase flow loops.

Table 2: $\quad$ Properties of different test rigs as reported by [11].

\begin{tabular}{|c|c|c|c|c|c|}
\hline Location & $\begin{array}{c}\text { Diameter } \\
\text { (inch) }\end{array}$ & $\begin{array}{l}\text { Length } \\
\text { (m) }\end{array}$ & $\begin{array}{l}\text { Maximum } \\
\text { flow rates }\end{array}$ & $\begin{array}{l}\text { Max. pres. } \\
\text { (bar) }\end{array}$ & Comments \\
\hline $\begin{array}{l}\text { SINTEF, } \\
\text { Norway }\end{array}$ & 4,8 and 12 & 1000 & $\begin{array}{c}\mathrm{U}_{\mathrm{sg}}: 12 \mathrm{~m} / \mathrm{s} \\
\mathrm{U}_{\mathrm{so}}: 3.5 \mathrm{~m} / \mathrm{s} \\
\text { (8" pipe) }\end{array}$ & 90 & $\begin{array}{l}\text { Not in } \\
\text { operation }\end{array}$ \\
\hline $\begin{array}{l}\text { IFE, } \\
\text { Norway }\end{array}$ & 4 & 20 & $\begin{array}{l}\mathrm{U}_{\mathrm{sg}}: 10 \mathrm{~m} / \mathrm{s} \\
\mathrm{U}_{\mathrm{so}}: 2 \mathrm{~m} / \mathrm{s} \\
\mathrm{U}_{\mathrm{sw}}: 2 \mathrm{~m} / \mathrm{s}\end{array}$ & 8 & $\begin{array}{l}\text { Dense gas } \\
\mathrm{SF}_{6} \text {, water, } \\
\text { exxol/diesel }\end{array}$ \\
\hline $\begin{array}{l}\text { Shell } \\
\text { Bacton, } \\
\text { UK }\end{array}$ & 8 & 280 & $\begin{array}{l}\mathrm{U}_{\mathrm{sg}}: 12 \mathrm{~m} / \mathrm{s} \\
\mathrm{U}_{\mathrm{so}}: 2.5 \mathrm{~m} / \mathrm{s}\end{array}$ & 75 & $\begin{array}{l}\mathrm{HC} \text { gas and } \\
\text { condensate } \\
\text { Not in } \\
\text { operation }\end{array}$ \\
\hline $\begin{array}{l}\text { Texaco, } \\
\text { US }\end{array}$ & 3 and 6 & 520 & $\begin{array}{l}\mathrm{U}_{\mathrm{sg}}: 11 \mathrm{~m} / \mathrm{s} \\
\mathrm{U}_{\mathrm{so}}: 2 \mathrm{~m} / \mathrm{s} \\
\mathrm{U}_{\mathrm{sw}}: 2 \mathrm{~m} / \mathrm{s}\end{array}$ & 10 & $\begin{array}{l}\text { HC gas, } \\
\text { crude oil and } \\
\text { water }\end{array}$ \\
\hline $\begin{array}{l}\text { Boussens, } \\
\text { France }\end{array}$ & 6 & 120 & $\begin{array}{l}\mathrm{U}_{\mathrm{sg}}: 7 \mathrm{~m} / \mathrm{s} \\
\mathrm{U}_{\mathrm{so}}: 3 \mathrm{~m} / \mathrm{s}\end{array}$ & 50 & $\begin{array}{l}\text { HC gas and } \\
\text { crude oil } \\
\text { Not in } \\
\text { operation }\end{array}$ \\
\hline $\begin{array}{l}\text { Imperial } \\
\text { College, } \\
\text { UK }\end{array}$ & 3 & 42 & $\begin{array}{l}\mathrm{U}_{\mathrm{sg}}: 14 \mathrm{~m} / \mathrm{s} \\
\mathrm{U}_{\mathrm{so}}: 1.5 \mathrm{~m} / \mathrm{s} \\
\mathrm{U}_{\mathrm{sw}}: 1.5 \mathrm{~m} / \mathrm{s} \\
\end{array}$ & 25 & $\begin{array}{l}\text { Air, lube oil } \\
\text { and water }\end{array}$ \\
\hline $\begin{array}{l}\text { Norsk } \\
\text { Hydro, } \\
\text { Norway }\end{array}$ & 3 & 120 & $\begin{array}{l}\mathrm{U}_{\mathrm{sg}}: 12 \mathrm{~m} / \mathrm{s} \\
\mathrm{U}_{\mathrm{so}}: 2.5 \mathrm{~m} / \mathrm{s} \\
\mathrm{U}_{\mathrm{sw}}: 2.5 \mathrm{~m} / \mathrm{s}\end{array}$ & 110 & $\begin{array}{l}\text { HC gas, } \\
\text { crude oil } \\
\text { and water }\end{array}$ \\
\hline
\end{tabular}


Table 3: Techniques for measuring reference phase flow rates, phase holdup and for identifying flow patterns.

\begin{tabular}{|l|l|l|l|l|}
\hline $\begin{array}{l}\text { Gas flow } \\
\text { rate }\end{array}$ & $\begin{array}{l}\text { Liquid flow } \\
\text { rate }\end{array}$ & $\begin{array}{l}\text { Phase } \\
\text { velocity }\end{array}$ & $\begin{array}{l}\text { Phase volumetric } \\
\text { fraction or mixture } \\
\text { density }\end{array}$ & $\begin{array}{l}\text { Flow pattern } \\
\text { visualization }\end{array}$ \\
\hline $\begin{array}{l}\text { Thermal } \\
\text { wave flow } \\
\text { meter }\end{array}$ & $\begin{array}{l}\text { Electro- } \\
\text { magnetic } \\
\text { meter }\end{array}$ & $\begin{array}{l}\text { X-correlation } \\
\text { techniques }\end{array}$ & $\begin{array}{l}\text { Gamma ray } \\
\text { densitometry }\end{array}$ & $\begin{array}{l}\text { High speed } \\
\text { video system } \\
\text { (visible } \\
\text { spectrum) }\end{array}$ \\
\hline $\begin{array}{l}\text { Hot wire } \\
\text { flow meter }\end{array}$ & $\begin{array}{l}\text { Ultrasonic } \\
\text { flow meter }\end{array}$ & $\begin{array}{l}\text { Laser } \\
\text { Doppler } \\
\text { Anemometer }\end{array}$ & $\begin{array}{l}\text { Capacitance/conducti } \\
\text { vity probes }\end{array}$ & \\
\hline $\begin{array}{l}\text { Coriolis } \\
\text { flow meter }\end{array}$ & $\begin{array}{l}\text { Coriolis flow } \\
\text { meter }\end{array}$ & $\begin{array}{l}\text { Particle } \\
\text { Image } \\
\text { Velocimetry }\end{array}$ & $\begin{array}{l}\text { X-ray or gamma-ray } \\
\text { tomography }\end{array}$ & \\
\hline $\begin{array}{l}\text { Vortex } \\
\text { flow meter }\end{array}$ & & & & \\
\hline
\end{tabular}

\subsection{Flow loops for the testing of Multiphase Flow Meters}

Multiphase Flow Metering (MFM) is the measurement of the flow rates of each individual phase in a multiphase flow. A review of MFM techniques is presented by [12].

There are a few accepted standards for evaluating the performance of multiphase flow and wet gas meters for oil and gas applications, but, as yet, no International Regulations exists. At present, the following options are available to the industry for the verification of a meter's performance:

- Testing is carried out at the manufacturer's own test facilities, such as the Schlumberger flow loop in Cambridge, UK or in a third-party test loop. Independent facilities include the National Engineering Laboratory (NEL) [4, 13] Cranfield University [14] and Imperial College London, all in the UK [7] the K-Lab Wet Gas loop in Norway [15] and the Colorado Engineering Experiment Station (CEESI) in the USA [16] have already carried out assessments of the performance of commercial meters and research prototypes.

- $\quad$ Testing is carried out in the field by the end user and the meter is tested against conventional test separators. There are only a few field flow loops, such as ENI's Trecate field in Italy [17] Petrobras' Atalaia field in Brazil [18] and the K-lab at Statoil Kaarstoe gas terminal [15] that allow controlled flow tests with real fluids. In these cases, the reference measurements are sufficiently accurate, but care must be taken when carrying out the tests (flow instabilities in the loop, possible malfunction of the test separator, etc.).

The initial testing of a meter is carried out in specialised laboratories where two- or three-phase flows can be established. In this type of testing, fluids with well known properties are used (e.g. water, air, synthetic oil or stabilised crude oil) and flow rates are controlled (corresponding to fixed gas and water fractions), which greatly reduces and even eliminates many uncertainties. This initial step defines the operational envelope of the meter and its measurement 
errors. The laboratory testing is then followed by field trials, which are required to identify potential operational problems, but may introduce more sources of error. These can be due to different upstream conditions (small variations in facilities layout may change the history of the flow), using real fluids instead of laboratory fluids of known properties, and the need for fluid property correlations to reconcile reference measurements with the meter readings taken at field operating conditions. Typically, the results of a field trial indicate the presence of error compensation.

Whatever the testing and verification environment is, the issue remains of comparing the flow rates predicted by the meter with those taken as reference measurements taken at the separator (in the case of field testing) or with conventional single-phase metering devices (in the case of laboratory testing). The results of calibrations are only as accurate as the reference measurements provided by the calibration facility [19]. When evaluating the results of a calibration campaign, the uncertainty of the reference measurements must be accounted for.

Flow loops used to verify and calibrate MFM's have either vertical or horizontal (or both) test sections in order to accommodate some or all of the possible metering configurations. Some loops have been specifically designed for testing at high GVF. Each facility has its own specifications in terms of operating pressure, phase flow rates, fluid properties, pipe diameter, length of the test section and available instrumentation and equipment.

\subsection{Flow loops for flow assurance studies}

The term "flow assurance" is thought to have been coined by Petrobras in the early 1990s as 'Garantia de Fluxo' which literally translates as 'Guarantee the Flow', or Flow Assurance [20]. It was originally related to the chemistry issues associated with deepwater oil exploitation. In a broader sense, flow assurance deals with anything that may impair the flow of hydrocarbons from reservoir to sales point. If the pressure drop in the overall production system is such that the reservoir fluids cannot be brought to surface, then this is a flow assurance issue. The same applies to corrosion or erosion of the pipe work of a production system and to the deposition of wax, paraffins, asphaltenes and hydrates. Some of the flow loops identified for this study are dedicated to the investigation of flow assurance issues. They are the Cold-Oil-Water Flow Assurance Loop, the Singleand Multi-Phase Paraffin Deposition Flow Loop and the Marathon Hydrate Assurance Loop at Tulsa University, the Multiphase Corrosion Flow Loop at the Ohio University and CEESI Hydrates flow loop.

\section{Future needs for niche experimental investigations}

This review of existing flow loops worldwide revealed that some specialist areas of research are still lacking dedicated test facilities. These niche areas include the study of sand transport in single- or multi-phase flows and the investigation of the dynamic interactions between flow in porous media and flow in pipes under transient flow conditions. 
Sand transport. The relevant mechanisms of sand particle transport are still poorly understood. Sand transport in oil-gas-sand production and transfer systems is governed by pressure, temperature, fluid composition, sand properties (density, grain dimension and shape) and momentum transfer between fluid and solid phases. In order to develop an insight into sand transport in multiphase flow systems, experimental testing is required. Several experimental and modelling techniques have been developed for the measurement and prediction of sand particle transport in oil-gas multiphase flow through pipes [21]. There exist non-intrusive techniques for taking flow measurements in solid-liquid-gas mixtures in pipes, including acoustic ultrasound, x-ray tomography, magnetic resonance imaging, neutron radiography, particle image velocimetry (PIV), laser Doppler anemometry, radioactive particle tracking, holographic interferometry and digital image analysis technique.

The visual measurement of sand hold-up and the development of a dedicated mechanistic model require purpose-built flow loops. Previous studies on sand transport were focused on the modelling of low sand fractions, which does not apply to situations where sand loading is more significant. To date, laboratory research on sand transport in multiphase flow systems has been limited to smallscale studies, which do not provide an adequate environment for the simulation of gas-oil-sand and oil-water-sand multiphase flow behaviour through slotted liners, perforated tunnels, wellbores, flowlines and production riser systems [21]. Also, the effects of high pressure and high temperature on such types of multiphase flows have been neglected.

The specific goals of an ad hoc sand transport research program should be as follows:

- $\quad$ Develop of a large-scale, high-pressure and high-temperature flow loop with dedicated instrumentation for the real-time monitoring of sand particle velocity, sand hold-up and sand distribution in pipes. This would allow one to evaluate the effects of sand particles on the characteristics of gas-oil and oil-water two-phase flows.

- Generate an experimental database to enhance the validation of mechanistic flow models for gas-oil-sand and oil-water-sand multiphase flow problems.

- Implement the validated flow models into in a user-friendly simulator for the design, performance analysis and optimisation of gas-oil-sand and oil-watersand systems.

To this aim, work is currently ongoing at Petroleum Engineering Department (ITE) Technical University of Clausthal.

Dynamic interactions between flow in porous media and flow in pipes under transient flow conditions. To date, a fully integrated solution that describes the dynamic interactions between multiphase flows in porous media and in connected wellbores under fully-transient conditions, and copes with compressible and incompressible fluids does not exist. Classical models of these interactions employ steady-state inflow performance relationships (IPR's) where the inflow from the porous medium is related to the pressure at the bottom of the pipe, which is related to the multiphase flow behaviour in the wellbore. The latter is also calculated from steady-state relationships (though these often lack a 
fundamental basis). Transitions between flow regimes can occur in the wellbore, often over a relatively small range of flow rates (i.e. over a relatively short time), in which case the use of steady-state IPR's may be erroneous. The best solution would be to couple together transient models for porous media and pipes. To develop and validate an integrated model of this type, laboratory experiments are required to mimic the behaviour of the near-wellbore region under unsteady-state flow conditions and the dynamic interactions between the porous medium and the well. To date, no flow loop exist for this specific purpose, although preliminary design calculations have been carried out by Falcone [2] and Costantini [22]. A main tank would contain both air and water at the same constant pressure, reproducing a boundary limit of the system: the constant reservoir pressure conditions at the edge of the drainage radius. A cylindrical porous medium, which reproduces the near-wellbore region, would be built using small glass beads accurately located in a Plexiglas cylinder in isotropic and homogeneous conditions. It would be installed at the bottom of a vertical pipe section (i.e. the well). Air and water from the main tank would be fed into the porous cylinder via a distribution manifold. After the flow becomes steady, transient flow periods could be imposed on the system by operating a surface valve or by varying the input flow rates. During the transient flow periods, measurements of pressure, temperature and void fraction could be made at different locations along the rig. Work is currently ongoing at Texas A\&M University to design and build a dedicated flow loop capable of simulating the integrated system made of reservoir, near-wellbore region and wellbore.

\section{Conclusions}

The development and validation of theoretical multiphase flow models requires measurements at controlled experimental conditions. This has given rise to a large number of multiphase flow loops around the world, some of which are also used intensively to test and validate multiphase flow meters and to investigate flow assurance issues.

This review shows the main features of a selection of facilities for the investigation of large scale multiphase flows, such as those that occur in the petroleum industry. Each flow loop in this review has been classified according to total reported length, maximum working diameter, inclination, operating pressure, length of test section and type of fluid.

However, it appears that some form of standardisation is required in the way flow loop capabilities are reported, particularly with regards to the flow rates that can be circulated in a given system. In most references, there is no indication of how the phase superficial velocities can vary in relation to different phase fractions in a two- or three-phase flow. Without this information, it is impossible to assess the full potential of a multiphase flow loop or infer which flow patterns it can reproduce. Hence, based on the information available in the public domain only, it is very difficult to identify the most appropriate facility for a given study area. 
Finally, this review shows that a flow loop cannot represent all possible situations and that some specialist areas of research are still lacking dedicated test facilities. These niche areas include the study of sand transport in single- or multi-phase flows and the investigation of the dynamic interactions between flow in porous media and flow in pipes under transient flow conditions.

\section{References}

[1] Hewitt, G.F., Three-phase gas-liquid-liquid flows in the steady and transient states, Nuclear Engineering and Design 235 (2005) 1303-1316.

[2] Falcone, G., "Modelling of flows in vertical pipes and its application to multiphase flow metering at high gas content and to the prediction of well performance", Ph.D. thesis, Imperial College, 2006.

[3] Brown, K.E., The Technology of Artificial Lift Methods I, PennWell, 1977.

[4] Dhulesi, H., Lopez, D., Critical Evaluation of Mechanistic Two-Phase Flow Pipeline and Well Simulation Models, SPE36611, SPE Annual Technical Conference \& Exhibition, Denver, Colorado, 6-9 October, 1996.

[5] Hewitt, G. F. and Jayanti, S., Prediction of the slug-to-churn flow transition in vertical two-phase flow, Int. J. Multiphase Flow, Vol. 18, pp 847-860, 1992.

[6] Hewitt, G.F., Reeks, M.W., Computational modelling of multi-phase flows, Chapter 7 in "Prediction of Turbulent Flows", Edited by G.F. Hewitt and J.C. Vassilicos, Cambridge University Press, 2005.

[7] Falcone, G., Hewitt, G.F., Lao, L., Richardson, S.M., ANUMET: A Novel Wet Gas Flowmeter, SPE84504, SPE Annual Technical Conference and Exhibition, Denver, Colorado, USA, 5-8 October 2003.

[8] SINTEF, www.sintef.no

[9] SwRI, www.swri.org

[10] Scott, S., Introduction to the Goals of the Event \& Texas A\&M Research, Multiphase Measurement Roundtable, Houston, 3 May 2006

[11] Valle, A. Multiphase Pipeline Flows in Hydrocarbon Recovery, Multiphase Science and Technology, Quarterly, Vol. 10, No. 1, 1998.

[12] Falcone, G., Hewitt, G.F., Alimonti, C., Harrison, B., Multiphase Flow Metering: Current Trends and Future Developments, Distinguished Author Series, Journal of Petroleum Technology, April 2002.

[13] Henry, M. Tombs, M., Duta, M., Two-Phase (Gas/Liquid) Floe Metering of Viscous Oil Using a Coriolis Mass Flow Meter: A Case Study, $24^{\text {th }}$ International North Sea Flow Measurements Workshop, 24-27 October 2006.

[14] Multiphase flow facility at Cranfield University, www.cranfield.ac.uk

[15] K-lab - advanced test facility for wet gas equipment, www.statoil.com

[16] Steven, R., A Discussion on Horizontally Installed Differential Pressure Meter Wet Gas Flow Performances, 24 ${ }^{\text {th }}$ International North Sea Flow Measurements Workshop, 24-27 October 2006. 
[17] Mazzoni, A., Halvorsen, M, Aspelund, A., Field Qualification FlowSys TopFlow Meter, Agip Test Facility Trecate, Italy, Milano, April 2001.

[18] Marruaz, Keyla S., Goncalvez, Marcelo A. L., Gaspari et al., Horizontal Slug Flow in a Large-Size Pipeline: Experimentation and Modeling. J. Braz. Soc. Mech. Sci. [online]. 2001, vol. 23, no. 4 [cited 2007-02-12], pp. 481-490.

[19] Corneliussen, S., Couput, J., Dahl, E., Dykesteen, E., Frøysa, K., Malde, E., Moestue, H., Moksnes, P.O., Scheers, L., Tunheim, H., Handbook of Multiphase Flow Metering, Revision 2, The Norwegian Society for Oil and Gas Measurement and The Norwegian Society of Chartered Technical and Scientific Professionals, March 2005.

[20] FEESA Limited, Flow Assurance \& Optimisation of Oil \& Gas Production, What is Flow Assurance? www.feesa.net.

[21] Bello, O. O., Reinicke, K. M. and Teodoriu, C., Experimental Study on Particle Behaviour in Simulated Oil-Gas-Sand Multiphase Production and Transfer Operations, ASME Fluids Engineering Division Summer Meeting \& Exhibition, July 17-20 2006, Miami, FL, USA

[22] Costantini, A., Dynamic interaction between the reservoir and the well during well testing, Dip.Ing. thesis, University "La Sapienza" of Rome \& Imperial College, October 2005

[23] Vilagines, R., Hall, A.R.W., Comparative Behaviour of Multiphase Flowmeter Test Facility, Oil and Gas Science and Technology, Rev. IFP, Vol. 58 (2003), No. 6, pp. 647-657

[24] Savidge, J., Flow Data for Natural Gas with Water and Hydrates, $24^{\text {th }}$ International North Sea Flow Measurements Workshop, 24-27 October 2006

[25] King, M.J.S., Hale, C.P., Lawrence, C.J., Hewitt, G.F., Characteristics of flowrate transients in slug flow, Int. J. Multiph. Flow, 1998, vol.24, no.5, pp.825-854

[26] Omurlu, C., Ozbayoglu, M.E., Friction Factors for Two-Phase Fluids for Eccentric Annuli in CT Applications, SPE 100145, SPE/ICoTA Coiled Tubing \& Well Intervention Conference \& Exhibition, The Woodlands, TX, 4-5 April 2006

[27] Sutton, R.P., Skinner, T.K., Christiansen, R.L., Wilson, B.L, Investigations of Gas Carryover with a Downward Liquid Flow, SPE 103151, 2006 SPE Annual Technical Conference and Exhibition, San Antonio, Texas, 24-27 September 2006

[28] BHRA, www.bhrgroup.co.uk

[29] SHELL, www.shell.com

[30] Memorial University Newfoundland, www.mun.ca

[31] IFE - Well Flow Loop, www.ife.no

[32] University of Tulsa, www.utulsa.edu

[33] King, M.J.S., Hale, C.P., Lawrence, C.J., Hewitt, G.F., Characteristics of flowrate transients in slug flow, Int. J. Multiph. Flow, 1998, vol. 24, no5, pp. $825-854$ 